\title{
Correspondance
}

\section{Challenges of teaching EBM}

A $s$ a clinician at an academic institution and possessor of a master's degree in clinical epidemiology, I support the principles of evidencebased medicine (EBM). Nevertheless, I have found it a challenge to teach $\mathrm{EBM}$, primarily because it is a significant challenge to practise EBM. The series by Peter Wyer and associates, ${ }^{1}$ especially the "tips for teachers" components, will go a long way toward assisting in the instruction of EBM, but unless trainees can use EBM practically and witness their teachers using it practically, we will not achieve the goal of EBM becoming a core competency of the next generation of physicians.

Part 1 in the series is an example. ${ }^{2}$ Using tip 2 ("Balancing benefits and adverse effects in individual patients") requires information on the background risk. This in turn requires efficient access to the types of information cited in the article. ${ }^{3,4}$ Efficient and effective access to that kind of information in most settings - either the over-busy hospital ward or the private office - is a challenge. (Ease of access is not a problem, because of ubiquitous Internet connectivity and the plethora of databases.)

In some areas of practice (particularly cardiovascular disease and cancer) information is available to feed into EBM approaches, such as the results of randomized controlled trials, background risks and other epidemiologic data. In other specialty fields, however, such as pediatrics, those data do not exist. In generalist fields such as family medicine the problem is the huge variety of patients and the constant shift from simple to complex conditions across age groups.

Two factors have hindered adoption of EBM: the challenge of teaching this material and the challenge of applying it. This series will (hopefully) help to address the former, but we have not done enough about the latter.

\section{Hal Siden}

Clinical Associate Professor

Department of Pediatrics

University of British Columbia

Vancouver, BC

\section{References}

1. Wyer PC, Keitz S, Hatala R, Hayward R, Barratt A, Montori V, et al. Tips for learning and teaching evidence-based medicine: introduction to the series [editorial]. CMA7 2004;171(4):347-8.

2. Barratt A, Wyer PC, Hatala R, McGinn T, Dans AL, Keitz S, et al, for the Evidence-Based Medicine Teaching Tips Working Group. Tips for learners of evidence-based medicine: 1 . Relative risk reduction, absolute risk reduction and number needed to treat. CMA7 2004;171(4):353-8

3. SHEP Cooperative Research Group. Prevention of stroke by anti-hypertensive drug treatment in older persons with isolated systolic hypertension. Final results of the Systolic Hypertension in the Elderly Program (SHEP). FAMA 1991;265: 3255-64.

4. SALT Collaborative Group. Swedish Aspirin Low-dose Trial (SALT) of $75 \mathrm{mg}$ aspirin as secondary prophylaxis after cerebrovascular events. Lancet 1991:338:1345-9.

DOI:10.1503/cmaj.1041600

Tam just finishing a master's degree in medical education, and my thesis work is closely related to the series on learning and teaching EBM. ${ }^{1}$ I have used the name DIETS (for "Disease management Interactive Teaching
Script") for my system, which incorporates up-to-date EBM in teaching the management of chronic disease to primary care doctors and nurses. The DIETS system includes presentations on topics such as hypertension and diabetes, which take the form of minilessons or "slide sets." In contrast to the teaching tips articles, ${ }^{2}$ which a reader can dip into and out of, each DIETS talk must be presented in its entirety, as a reflection of the longitudinal nature of primary care. Another difference is that feedback in DIETS is formalized, appearing in the third slide of each set, whereas feedback is less structured in the teaching tips. An important similarity between the scripts used in the DIETS system and those in the EBM series is that the teaching of particular points conforms with the suggestions of Peile and colleagues, ${ }^{3}$ who discussed the notion of threshold concepts - key concepts that, once understood, allow learners to understand, interpret or view something in a different way. Until that threshold is crossed, the student will struggle to progress.

I have used part 1 of the teaching tips series ${ }^{2}$ to analyze the synopsis ${ }^{4}$ (published recently in $C M A 7$ ) of the

\section{Mécanisme de présentation des lettres}

Le site amélioré des cyberlettres du JAMC est désormais le portail de réception de tous les textes destinés à la chronique Lettres. Pour rédiger une cyberlettre, consultez un article sur le site www.jamc.ca et cliquez ensuite sur le lien «Lettres électroniques : répondre à cet article», dans la boîte en haut à droite de l'article. Toutes les cyberlettres seront étudiées pour une éventuelle publication dans le journal imprimé.

Les lettres répondant à un article publié dans le JAMC sont plus susceptibles d'être acceptées pour publication imprimée si elles sont présentées dans les deux mois de la date de publication de l'article. Les lettres acceptées pour publication imprimée sont révisées en fonction du style du JAMC et raccourcies au besoin (elles doivent habituellement compter au maximum 250 mots). 